\title{
DESTABILIZATION OF MODEL WASTEWATER IN THE CHEMICAL COAGULATION PROCESS
}

\author{
DESTABILIZACJA ŚCIEKÓW MODELOWYCH \\ W PROCESIE KOAGULACJI CHEMICZNEJ
}

\begin{abstract}
This paper discusses the results of laboratory analyses of the coagulation and flocculation of model wastewater. The investigated wastewater was susceptible to treatment by chemical coagulation. The effectiveness of two commercial coagulants, PAC produced at the DEMPOL-ECO Chemical Plant and PIX manufactured by KEMIPOL, was compared. A mathematical model relying on a second-degree polynomial was used to describe and analyze experimental data. In each case, the parabola minimum point was a precisely determined coagulant dose, regarded as the optimal dose. The application of a coagulant dose higher than the optimal dose reduced the effectiveness of wastewater treatment by coagulation. A detailed analysis of turbidity, suspended solids, total phosphorus and pollutant removal measured by the COD test revealed that PAC was a more effective and a more efficient coagulant than PIX. The risk of coagulant overdosing was greater with the use of PAC than PIX.
\end{abstract}

Keywords: synthetic wastewater, coagulant dose, zeta potential

Primary chemical coagulation is the initial stage of wastewater treatment. Coagulation, aggregation and flocculation lead to colloidal system destabilization [1]. Aluminum and iron(III) cations found in the most commonly applied inorganic coagulants [2-6], PAC $(\mathrm{PACl})$ and PIX, are used for primary coagulation of negatively charged wastewater colloids. Aggregation and flocculation are the result of processes in which particles formed during latent coagulation are combined into larger agglomerates-flocs [7, 8]. In the process of wastewater coagulation $[9,10]$, the key problem is the choice of coagulant and the precise determination of its optimum dose [11-13]. Both coagulant deficiency and excess may reduce coagulation efficiency $[14,15]$. An excess of coagulant may lead to partial release of impurities as a result of peptization of the sludge formed in an environment created by the optimum coagulant dose. Electrocoagulation is a viable alternative to chemical coagulation $[4,16]$.

\footnotetext{
${ }^{1}$ Department of Chemistry, Faculty of Environmental Management and Agriculture, University of Warmia and Mazury, pl. Łódzki 4, 10-957 Olsztyn, Poland, phone +48 8952336 86, fax +48 895234801 , email: lechs@uwm.edu.pl

*Corresponding author: marta.kosobucka@uwm.edu.pl
} 
Theoretically, under optimal coagulant dose conditions, the zeta potential $\zeta$ of the coagulated system should be equal to $0[14,17]$. However, practice often shows that the maximum pollutant removal rates are reached at $\zeta \neq 0$ [18]. Therefore, the jar test procedure is still widely applied, since it permits an empirical determination of the optimal coagulant dose $[11,13,19]$. From a scientific point of view, however, the coagulant dose can be most precisely determined based on an original, large experimental database fitted into a specific mathematical model. This paper presents the results of laboratory analyses of model wastewater coagulation. The obtained database was fitted into a parabola.

\section{Methods}

The experimental materials comprised model wastewater obtained by dissolving identical, precisely weighed, samples of NESTLE powdered milk in $2000 \mathrm{~cm}^{3}$ of an aqueous solution which each time contained $10 \mathrm{~cm}^{3}$ phosphate buffer as an additional source of phosphorus and to prevent $\mathrm{pH}$ changes. Another $1 \mathrm{dm}^{3}$ phosphate buffer contained $8.80 \mathrm{~g} \mathrm{KH}_{2} \mathrm{PO}_{4}$ and $101.0 \mathrm{~g} \mathrm{~K}_{2} \mathrm{HPO}_{4}$.

Commercial (concentrated) coagulant solutions were added to seven beakers containing $200 \mathrm{~cm}^{3}$ freshly prepared wastewater, using a pipette designed for this purpose, in the following amounts:

- $\quad$ beaker No. $1=0$ drops of coagulant,

- $\quad$ beaker No. $2=3$ drops of coagulant,

- $\quad$ beaker No. 3 = 5 drops of coagulant,

- etc.

The volume of 100 drops was measured (in five replications each time) to establish the exact amount of the dosed coagulant in $\mathrm{mg}$ per $\mathrm{dm}^{3}$ wastewater. The volume of one drop (Standard Deviation $\pm 0.2 \%$ ) was measured in the same way. After the coagulant had been added to the wastewater, the solution was stirred vigorously (approx. $150 \mathrm{rpm}$ ) for around 15 seconds, and after $30 \mathrm{~min}$ sedimentation, $2 \mathrm{~cm}^{3}$ samples for physicochemical analyses were collected above the sediment layer with a pipette. Total COD, total phosphorus, suspended solids and $\mathrm{pH}$ were determined in the samples by standard methods [20], using a $\mathrm{HACH}$ spectrophotometer. A coagulation-flocculation test was performed in seven replications for each coagulant. The two highest and the two lowest values were always rejected, and means and standard deviations (SD) were calculated from the remaining results each time. The results were used to establish the optimal coagulant dose (see the Results and Discussion section). Two commercial inorganic coagulants were used:

1) PAC - produced at the DEMPOL-ECO Chemical Plant, in the form of a light-gray aqueous solution with density of $1.28 \mathrm{~g} \cdot \mathrm{dm}^{-3}$ and the following composition: $20.68 \% \mathrm{Al}_{2} \mathrm{O}_{3}, 6.5 \% \mathrm{Cl}^{-}, 0.02 \% \mathrm{Fe}$,

2) PIX - manufactured by KEMIPOL, with the chemical formula $+/-\mathrm{Fe}_{2}\left(\mathrm{SO}_{4}\right)_{3}$, in the form of a dark-brown $40-42 \%$ solution with density of $1.5-1.6 \mathrm{~g} \cdot \mathrm{dm}^{-3}$ and the following composition: $11-12.6 \% \mathrm{Fe}^{3+}, 0.2-0.75 \mathrm{Fe}^{2+}$.

Electrokinetic potential $\zeta$, referred to as zeta potential, was also determined. The potential of colloidal particles moving in an electric field on the stationary layer in an electrophoresis chamber was measured using the Malvern Zeta Sizer 3000. Each time, a sample taken with a syringe was placed in a measuring vessel containing two electrodes. Before each measurement, the vessel was rinsed with the analyzed solution. Each 
measurement was repeated five times, and average values with their standard deviations are presented graphically in this paper.

\section{Results and discussion}

The analyzed model wastewater had $\mathrm{pH}_{\mathrm{o}}=7.5$. An increase in the dose of $\mathrm{Fe}$ and $\mathrm{Al}$ coagulants led to a decrease in $\mathrm{pH}$, to $\approx 5.5$ and $\approx 6.0$, respectively, as a result of cationic hydrolysis of the applied coagulants, eg:

$$
\begin{gathered}
10 \mathrm{Al}(\mathrm{OH})_{2.1}{ }^{0.9+}+\mathrm{H}_{2} \mathrm{O} \leftrightarrow 10 \mathrm{Al}(\mathrm{OH})_{2.2}{ }^{0.8+}+\mathrm{H}^{+} \\
\mathrm{Fe}(\mathrm{OH})_{0.1}{ }^{2.9+}+\mathrm{H}_{2} \mathrm{O} \leftrightarrow \mathrm{Fe}(\mathrm{OH})_{1.1}{ }^{1.9+}+\mathrm{H}^{+}
\end{gathered}
$$

Many specific $\mathrm{Al}$ and $\mathrm{Fe}$ cations $[14,21]$ can be formed in the system, depending on wastewater content and concentration. The hydrolysis of coagulants is the first step in the formation of positive sols in the system, such as:

$$
\left[\mathrm{Al}_{\mathrm{n}}(\mathrm{OH})_{3 \mathrm{n}-\mathrm{x}}\right]^{\mathrm{x}+} \text { or }\left[\mathrm{Fe}_{\mathrm{m}}(\mathrm{OH})_{3 \mathrm{~m}-\mathrm{y}}\right]^{\mathrm{y}+}
$$

Flocculation and phase separation resulting from the sedimentation (or flotation) of post-coagulation sludge are the final stages of wastewater treatment by chemical coagulation.

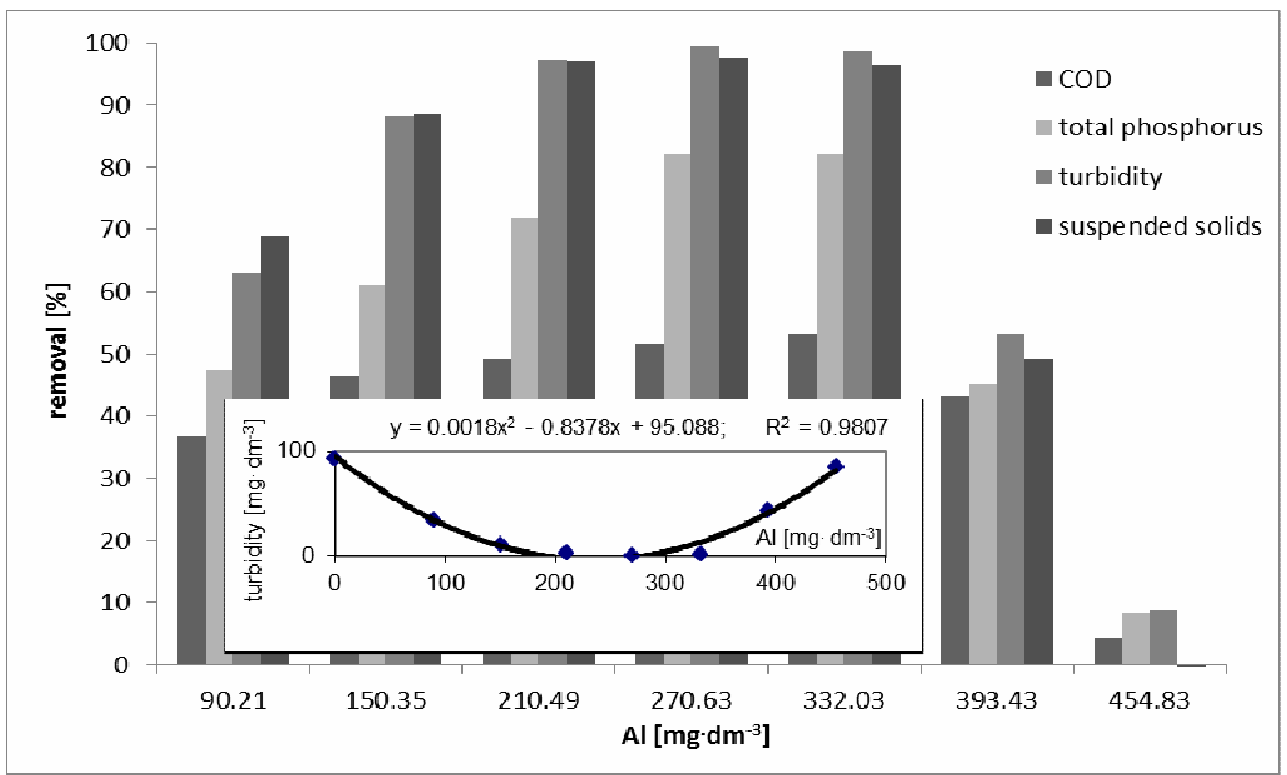

Fig. 1. Changes in COD, total phosphorus, turbidity and suspended solids with the use of PAC

Changes in COD, total phosphorus concentrations, turbidity and suspended solids, respectively, in wastewater coagulated with the use of PAC are shown in Figure 1. Each time, an increase in the dose of $\mathrm{Al}^{3+}$ ions increased the effectiveness of impurity removal. When the minimum impurity concentrations corresponding to the maximum removal efficiency had been reached, a further increase in PAC dose negatively affected the 
parameters of the wastewater treatments process. Such a course of the removal $=f($ coagulant dose $)$ dependency is typical of second degree polynomials, eg a parabola describing turbidity removal from coagulated wastewater:

$$
y=0.0018 x^{2}+0.8378 x+95.088
$$

The good fitting of the database to the applied mathematical model is confirmed by high values of determination coefficient $R^{2}$ at $>0.9$, eg $R^{2}=0.98$ for a parabola illustrating turbidity removal from coagulated wastewater (Fig. 1).

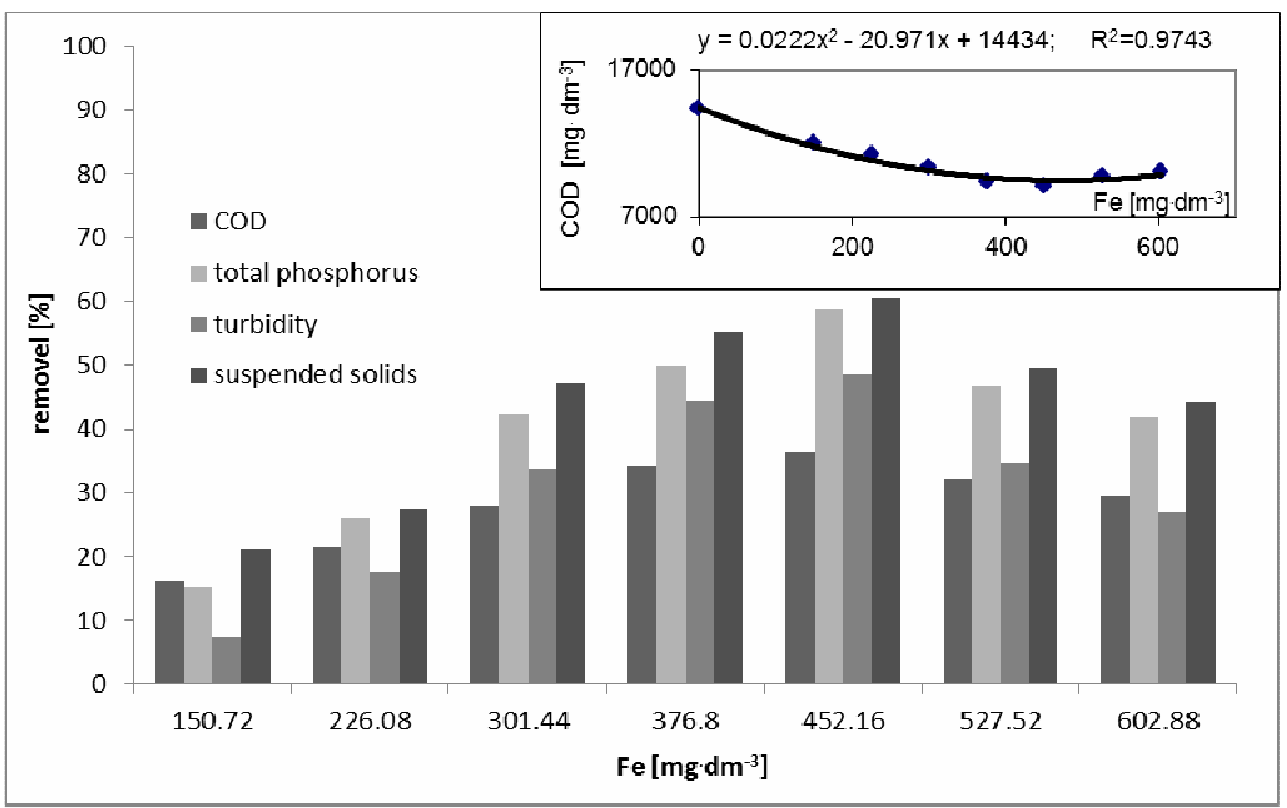

Fig. 2. Changes in COD, total phosphorus, turbidity and suspended solids with the use of PIX

Table 1

Average optimal coagulant doses in $\mathrm{mg} \mathrm{Al}$ (PAC) and Fe (PIX) per $\mathrm{dm}^{3}$ of wastewater

\begin{tabular}{|c|c|c|c|c|c|c|}
\hline & COD & Phosphorus & Turbidity & $\begin{array}{c}\text { Suspended } \\
\text { solids }\end{array}$ & Mean & SD \\
\hline PAC & 241 & 236 & 233 & 230 & 235 & 4.7 \\
\hline PIX & 472 & 420 & 470 & 446 & 452 & 24 \\
\hline
\end{tabular}

Table 2

Effectiveness of the optimal doses of PAC

\begin{tabular}{|c|c|c|c|c|}
\hline $\begin{array}{c}\text { Dose } \\
{\left[\mathrm{mg} \mathrm{Al} \cdot \mathbf{d m}^{-3}\right]}\end{array}$ & $\begin{array}{c}\text { Wastewater components } \\
{\left[\mathrm{mg} \cdot \mathrm{dm}^{-3}\right]}\end{array}$ & $\begin{array}{c}\text { Removal } \\
{\left[\mathrm{mg}^{\prime} \cdot \mathbf{d m}^{-3}\right]}\end{array}$ & $\begin{array}{c}\text { Average } \\
\text { removal } \\
{[\%]}\end{array}$ & $\begin{array}{c}\text { Effectiveness } \\
\text { [mg component } \\
\text { /mg Al] }\end{array}$ \\
\hline 241 & $\operatorname{COD}\left(\mathrm{COD}_{\mathrm{o}}=14500 \pm 500\right)$ & 8336 & 56 & 35 \\
\hline 236 & 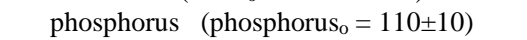 & 96 & 79 & 0.41 \\
\hline 233 & turbidity $\left(\right.$ turbidity $_{0}=95 \pm 5$ ) & 93 & 100 & 0.40 \\
\hline 230 & suspended solids $\left(\right.$ suspended solids $_{\mathrm{o}}=70 \pm 5$ ) & 70 & 94 & 0.30 \\
\hline
\end{tabular}


Effectiveness of the optimal doses of PIX

\begin{tabular}{|c|c|c|c|c|}
\hline 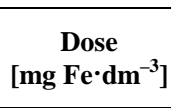 & $\begin{array}{c}\text { Wastewater components } \\
{\left[\mathrm{mg} \cdot \mathbf{d m}^{-3}\right]}\end{array}$ & $\begin{array}{c}\text { Removal } \\
{\left[\mathrm{mg}^{\left.-\mathbf{d m}^{-3}\right]}\right.}\end{array}$ & $\begin{array}{c}\text { Average } \\
\text { removal } \\
{[\%]}\end{array}$ & $\begin{array}{c}\text { Effectiveness } \\
\text { [mg component } \\
\text { /mg Fe] }\end{array}$ \\
\hline 472 & $\left(\mathrm{COD}_{\mathrm{o}}=14500 \pm 500\right)$ & 4768 & 34 & 10 \\
\hline 420 & 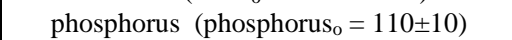 & 47 & 41 & 0.11 \\
\hline 470 & turbidity (turbidity ${ }_{o}=95 \pm 5$ ) & 39 & 39 & 0.08 \\
\hline 446 & suspended solids $\left(\right.$ suspended solids $_{o}=70 \pm 5$ ) & 36 & 49 & 0.08 \\
\hline
\end{tabular}

Changes in COD, phosphorus concentrations, turbidity and suspended solids, respectively, in wastewater coagulated with PIX are presented in Figure 2. Each time, an increase in the dose of $\mathrm{Fe}^{3+}$ ions increased the effectiveness of impurity removal, similarly as in the case of $\mathrm{Al}^{3+}$ (Fig. 1, PAC). When the minimum impurity concentrations corresponding to the maximum removal efficiency had been reached, a further increase in PIX dose negatively affected the parameters of the wastewater treatments process, which was also observed for PAC (Fig. 1). The equation of a parabola describing COD removal from coagulated wastewater (Fig. 2) takes on the form:

$$
y=0.0222 x^{2}+20.971 x+14434
$$

The good fitting of the database to the applied mathematical model is confirmed by a high value of determination coefficient, $R^{2}=0.97$ (Fig. 2). Based on Figures 1 and 2, the following values presented in Tables 1,2 and 3 were calculated:

- Table 1 - average optimal coagulant doses,

- Table 2 - effectiveness of average optimal PAC doses,

- $\quad$ Table 3 - effectiveness of average optimal PIX doses.

The average optimal dose of PAC (Table 1) at $235 \mathrm{mg} \mathrm{Al} \cdot \mathrm{dm}^{-3}$ (at SD = 5), calculated as the mean abscissa of the parabola's minimum (Fig. 1), resulted in the complete removal of turbidity and suspended solids from the coagulated wastewater, whereas the optimal dose of PIX (Table 1) at $452 \mathrm{mg} \mathrm{Fe} \cdot \mathrm{dm}^{-3}(\mathrm{SD}=24)$ decreased turbidity to approx. $58 \mathrm{mg} \cdot \mathrm{dm}^{-3}$ and suspended solids to approx. $36 \mathrm{mg} \cdot \mathrm{dm}^{-3}$ (Fig. 2). COD and total phosphorus concentrations in wastewater treated with PAC decreased to approx. 6400 and $25 \mathrm{mg} \cdot \mathrm{dm}^{-3}$, respectively (Fig. 1). The optimal dose of PIX (Fig. 2) decreased COD and total phosphorus levels only to approx. 9600 and $50 \mathrm{mg} \cdot \mathrm{dm}^{-3}$, respectively. It was calculated that $1 \mathrm{mg} \mathrm{Al}$ from PAC was successful in removing $0.3-0.4 \mathrm{mg}$ of turbidity and suspended solids, whereas $1 \mathrm{mg}$ Fe from PIX lowered the above values by only $0.08 \mathrm{mg}$. In wastewater samples coagulated with PAC (Fig. 1), $35 \mathrm{mg}$ COD was removed by $1 \mathrm{mg} \mathrm{Al}$, and in samples treated with the PIX (Fig. 2) the relevant reduction was only $10 \mathrm{mg}$ per $1 \mathrm{mg} \mathrm{Fe}$. The efficiency of total phosphorus removal was determined at 0.41 per $1 \mathrm{mg} \mathrm{Al}$ and only 0.11 per $1 \mathrm{mg} \mathrm{Fe}$.

A direct comparison of purification efficiency (Fig. 2) indicates that lower doses of PAC produced better results than higher doses of PIX. The above can be attributed to the varied effects of chloride anions from PAC and sulfate(VI) anions from PIX on the coagulation process, and to the more probable presence of pre-hydrolyzed forms of aluminum in PAC than of pre-hydrolyzed forms of iron in PIX.

According to some authors $[14,17,22], \mathrm{Cl}^{-}$ions are more likely to contribute to the efficiency of flocculation than $\mathrm{SO}_{4}{ }^{2-}$ ions. However, this view could result from 
an oversimplified interpretation of the Schultz-Hardy rule. The "self-coagulating" ability of sulfate(VI) anions from PIX is at least 10-fold higher in comparison with chloride ions from PAC. Therefore, the PAC sol is more stable than the PIX sol. Hence, the destabilization of $\left\{\mathrm{Al}(\mathrm{OH})_{3}\right\}_{\mathrm{n}}$ sol requires more negatively charged impurities in the treated wastewater than the destabilization of $\left\{\mathrm{Fe}(\mathrm{OH})_{3}\right\}_{\mathrm{n}}$ sol. Since the $\left\{\mathrm{Fe}(\mathrm{OH})_{3}\right\}_{\mathrm{n}}$. sol is more easily destabilized, it is less capable of "consuming" wastewater impurities.

$\mathrm{PAC}$ is also deemed to deliver superior results in comparison with PIX due to the fact that PAC usually contains ions with a valence of above +3 from $\mathrm{Al}_{8}(\mathrm{OH})_{20}^{4+}$ and, in particular, the stable $\mathrm{AlO}_{4} \mathrm{Al}_{12}(\mathrm{OH})_{2}\left(\mathrm{H}_{2} \mathrm{O}\right)_{12}^{7+}$ polycation $[14,21,22]$. The Schultz-Hardy rule can be easily extrapolated:

$$
\mathrm{Ka}^{+}: \mathrm{Ka}^{2+}: \mathrm{Ka}^{3+}: \mathrm{Ka}^{4+}: \ldots \mathrm{Ka}^{7+}=1:(10) 20: 500: 10000: \ldots 80000000
$$

to demonstrate that the mere addition of $0.1 \%$ of the above $\mathrm{Al}_{13}^{7+}$ polycation in the coagulant (accounting for the content of seven aluminum ions) can result in an even 10-fold increase in the coagulating capacity of PAC as an inorganic coagulant. Stable $\mathrm{Al}_{13}^{7+}$ polycations and other aluminum ions $(+4,+5,+6)$ play a key role at the initial (and the most important) stage of latent coagulation. They may efficiently neutralize negatively charged wastewater impurities responsible for COD, turbidity and suspended solids. The last stage of final coagulation of lyophobic sol is often referred to as sweep flocculation [23]. Contrary to the subtle and effective phase of latent coagulation, sweep flocculation is characterized by high coagulant consumption which decreases the effectiveness of wastewater treatment.

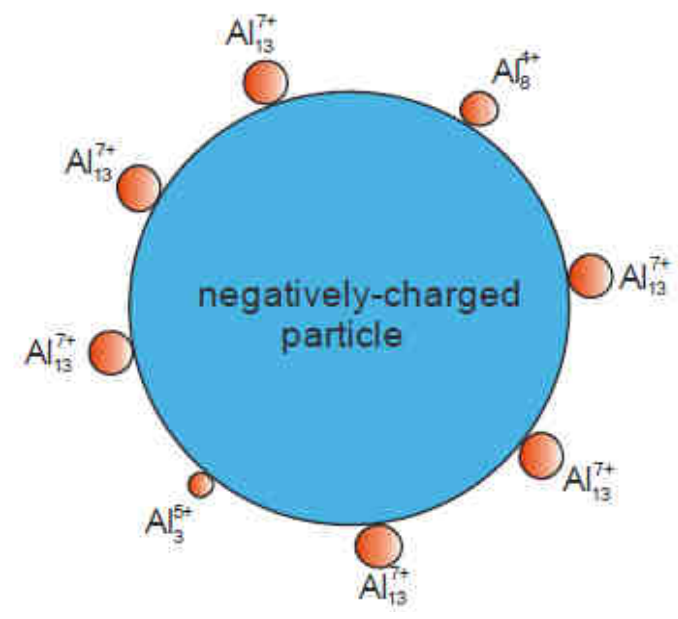

Fig. 3. Neutralization of wastewater charge

The mechanism underlying charge neutralization and adsorption of $\mathrm{AlO}_{4} \mathrm{Al}_{12}(\mathrm{OH})_{2}\left(\mathrm{H}_{2} \mathrm{O}\right)_{12}^{7+}$ and other aluminum ions $(+4,+5,+6)$ on negatively charged compounds responsible for COD is schematically presented in Figure 3. The process leads to the formation of sludge agglomerates, aggregates and flocs which may be separated from 
treated wastewater in the process of sedimentation or flotation. It should be noted that certain amounts of hydrogen ions formed as a result of hydrolysis of high coagulant doses may support the destabilization of negative charged impurities.

A parabolic shape of the curve illustrating changes in COD, phosphorus concentrations, turbidity and suspended solids, subject to the applied coagulant dose (PAC - Fig. 1, PIX - Fig. 2), suggests an overdosing phenomenon in the coagulation process. Duan and Gregory [14] presented a similar parabola for turbidity removal. Unfortunately, they did not use any mathematical formulas to describe quantitative changes in wastewater turbidity. In the present study, PIX (Fig. 2) produced a smaller overdosing effect than PAC (Fig. 1). Most probably, excessive doses of both coagulants led to colloidal system overcharging in coagulated wastewater, increasing colloid stability. Such a phenomenon was also observed by Duan and Gregory [14]. Colloidal system overcharging, sometimes accompanied by sludge peptization, always reduces wastewater purification efficiency, mostly with regard to COD and phosphorus removal.

Even an insignificant drop in $\mathrm{pH}$ caused by excessive coagulant doses may lead to the protonation of $\mathrm{PO}_{4}{ }^{3-}$ ions, thus increasing undesirable phosphate mobility (from the sludge to the solution) in the system. The complexation properties of $\mathrm{Al}^{3+}$ and (in particular) $\mathrm{Fe}^{3+}$ prevent the displacement of phosphate ions to the post-coagulation sludge, which negatively impacts wastewater treatment. In some cases, eg during turbidity removal, the highest, excessive PAC dose, led to an increase in turbidity in coagulated wastewater, up to the values equal to those determined for untreated wastewater. The above could be attributed to the presence of a undestabilized, light-scattering $\left\{\mathrm{Al}(\mathrm{OH})_{3}\right\}_{\mathrm{n}}$ sol in the system, or sol overcharging [14] to the agglomerate in the solution above the post-coagulation sludge. It seems that the above processes could have been responsible for high (and correlated) levels of turbidity and suspended solids in coagulated wastewater, particularly at the highest PAC dose.

The popular interpretation of the process of phosphate removal from chemically coagulated wastewater may raise controversy. According to most authors, the process involves co-precipitation of orthophosphate $(\mathrm{V})$ and hydroxide. From the chemical perspective, is seems that the probability of $\mathrm{AlPO}_{4} \downarrow$ or $\mathrm{FePO}_{4} \downarrow$ precipitation at $\mathrm{pH}=6$ is low in wastewater, ie a diluted solution of orthophosphate ions. Competitive $\mathrm{Al}(\mathrm{OH})_{3} \downarrow$ and $\mathrm{Fe}(\mathrm{OH})_{3} \downarrow$ precipitates are sparingly soluble, and $\mathrm{pH}<7$ prevents the formation of neutral $\mathrm{PO}_{4}{ }^{3-}$ anions. In such a situation, phosphates of the following types: $\mathrm{Al}_{2}\left(\mathrm{HPO}_{4}\right)_{3}$, $\mathrm{Fe}_{2}\left(\mathrm{HPO}_{4}\right)_{3}, \mathrm{Al}\left(\mathrm{H}_{2} \mathrm{PO}_{4}\right)_{3}$ and $\mathrm{Fe}\left(\mathrm{H}_{2} \mathrm{PO}_{4}\right)_{3}$ are formed. Their solubility is at least average, or even high in the last two cases. For the above reasons, phosphorus removal from chemically coagulated wastewater may be viewed as a process of permanent phosphate sorption on positively charged colloidal sorbents, $\left\{\mathrm{Al}(\mathrm{OH})_{3}\right\}_{\mathrm{n}}$ or $\left\{\mathrm{Fe}(\mathrm{OH})_{3}\right\}_{\mathrm{m}}$. At the stage of sweep flocculation, phosphates may be adsorbed directly on the flocs of respective hydroxides.

Figure 4 shows the process of phosphate sorption on colloidal sorbents, ie aluminum hydroxide or iron(III) hydroxide. It seems that the above process is responsible for phosphorus removal from wastewater coagulated with PAC and PIX. Electrostatic attraction of the positively charged sorbent and the negatively charged sorbate could affect the process of phosphate adsorption during wastewater coagulation. Due to such interactions between cations or hydroxy (poly)cations and hydrogen anions (hydrogen phosphate anions), the considered sorption process should have chemical character [24, 25]. However, the mechanism of removing other negatively charged phosphorus compounds (including 
organic compounds) from coagulated wastewater may be similar. Such an interpretation of phosphorus removal from wastewater coagulated with PAC and PIX suggests that there are a limited number of sites for the adsorbed particles on the adsorbent surface. A single site can be used only by a single adsorbed particle. According to the basic chemical adsorption theory, the adsorbent forms a monolayer of adsorbate particles on its surface. They interact with adsorption centers, while their mutual interactions are weak or absent. Adsorption is limited since a multilayer cannot be formed. Desorption (the opposite of adsorption) is also possible. More frequent and more effective interactions with the adsorbent surface are observed at higher phosphate concentrations. The adsorbent surface is energetically homogeneous, and adsorption energy remains constant.

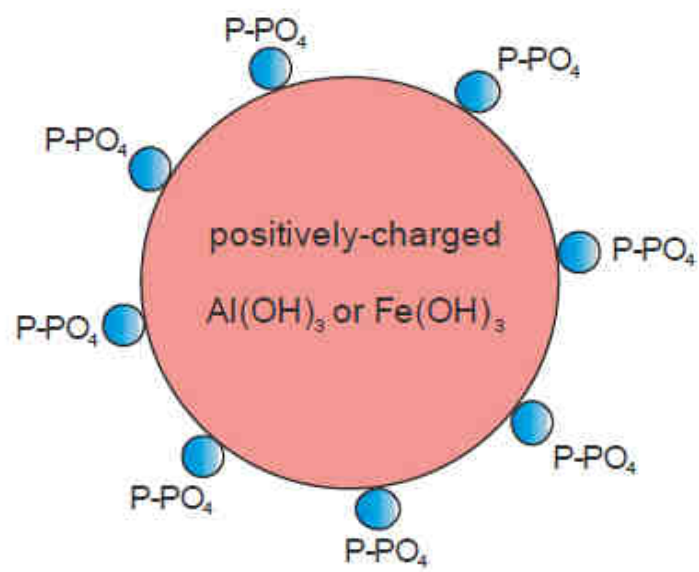

Fig. 4. Chemical sorption of phosphate phosphorus on colloidal sorbents of the $\left\{\mathrm{Al}(\mathrm{OH})_{3}\right\}_{\mathrm{n}}$ and $\left\{\mathrm{Fe}(\mathrm{OH})_{3}\right\}_{\mathrm{m}}$ type

The phenomena that occur during chemical coagulation are closely related to the structure of the so called electrical double layer, sometimes referred to as the electrochemical layer, or - more precisely - to the surface potential of coagulating and coagulated colloidal particles. Coagulation involves colloidal system destabilization, followed by the formation of agglomerates and aggregates. Aggregation leads to the process of floc formation, known as flocculation. Colloidal system stability is determined by the values of electrokinetic potential $\zeta[17,18]$. Higher absolute values of $\zeta$ imply a greater repulsive effect between colloidal particles, and higher stability. When the value of $\zeta$ ranges from -30 to $+30 \mathrm{mV}$, colloidal particles easily aggregate, due to relatively small forces of electrostatic repulsion.

Figure 5 presents changes in zeta potential $\zeta$ of wastewater coagulated with PAC. When added to the treated wastewater, the coagulant dissociates. Positively charged aluminum cations and (hydroxy) polycations formed as a result of coagulant dissociation and hydrolysis eliminate water dipoles from the negatively charged surfaces of colloidal particles, and become permanently attached to those surfaces. The above leads to a decrease in electric potential in the Stern layer, and in the electrokinetic zeta potential. The forces of electrostatic repulsion between colloidal particles decrease, latent and slow coagulation 
begins [8], and flocs of post-coagulation sludge are formed in the system. Cations may appear in the adsorption layer if coagulant dose is further increased. From that moment, the value of potential $\zeta$ starts to change and the charge of the entire colloidal system comprising wastewater impurities and coagulant particles changes from negative to positive. At higher PAC doses, an alternative scenario is the formation of certain amounts of undestabilized colloids of the $\left\{\mathrm{Al}(\mathrm{OH})_{3}\right\}_{\mathrm{n}}$ coagulant responsible for the positive value of zeta potential (Fig. 5) and high levels of suspended solids and turbidity (Fig. 1). When the dose of approx. $330 \mathrm{mg} \mathrm{Al} \cdot \mathrm{dm}^{-3}$ is exceeded, wastewater treatment efficiency decreases with respect to COD and phosphorus removal (Fig. 1), which may be attributed to the overcharging of the colloidal system.

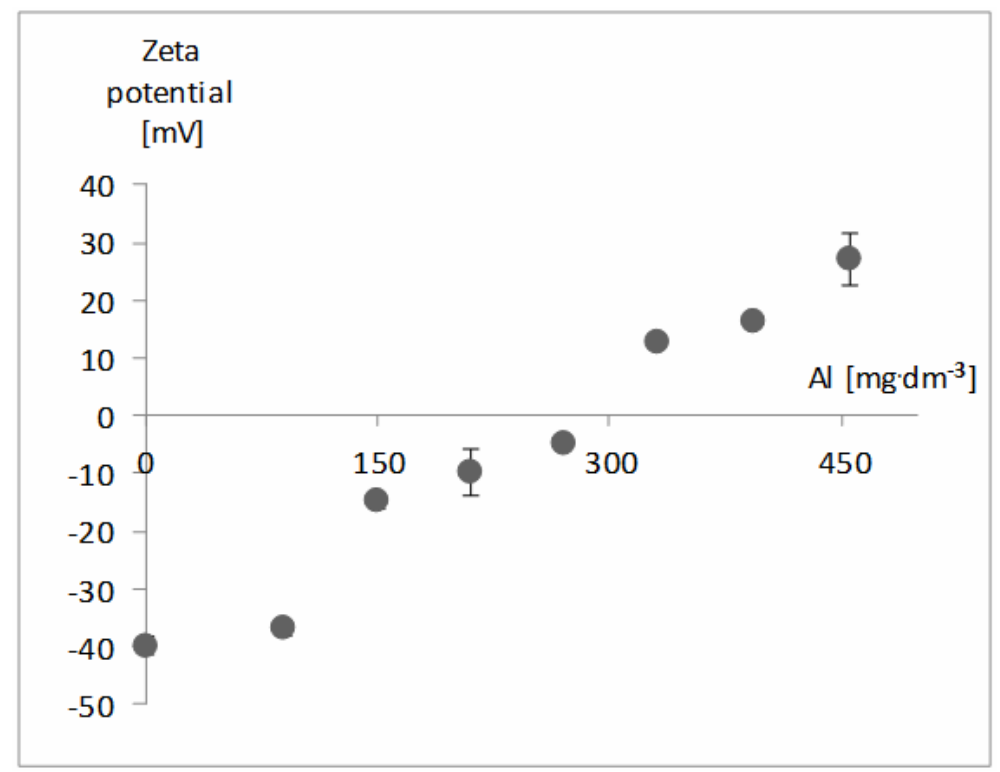

Fig. 5. Changes in zeta potential $\zeta$ of wastewater coagulated with PAC. Values of standard deviation (SD) are introduced on the experimental points

The changes in zeta potential $\zeta$ (Fig. 5) described above suggest that impurity removal from wastewater coagulated with PAC at a dose $\leq$ the optimal dose involves destabilization resulting from the neutralization of the surface charge of impurities during slow and latent coagulation. Similar conclusions were formulated by [26].

Figure 6 illustrates changes in zeta potential $\zeta$ of wastewater coagulated with PIX. They are correlated with changes in the other parameters of coagulated wastewater, although in a different way than in the case of PAC. As shown in Figure 6, the dose of $452 \mathrm{mg} \mathrm{Fe} \cdot \mathrm{dm}^{-3}$ may be considered optimal in the process of wastewater treatment with PIX, because at $452 \mathrm{mg} \mathrm{Fe} \cdot \mathrm{dm}^{-3}$ the maximum value of zeta potential is reached. Up to this dose of PIX, negatively charged colloids are destabilized and neutralized as in the case of PAC. When the dose of $452 \mathrm{mg} \mathrm{Fe} \cdot \mathrm{dm}^{-3}$ is exceeded, the effectiveness of wastewater treatment decreases insignificantly, but the value of zeta potential does not increase any further, as with PAC, but it decreases to approx. $-25 \mathrm{mV}$. The decrease in the zeta potential of the 
system in the presence of high PIX doses could result from lower stability of the $\left\{\mathrm{Fe}(\mathrm{OH})_{3}\right\}_{\mathrm{m}}$ colloid, compared with the $\left\{\mathrm{Al}(\mathrm{OH})_{3}\right\}_{\mathrm{n}}$ colloid $(\mathrm{PAC})$ at higher coagulant concentrations. The destabilizing colloid forms aggregates and flocs, partially without the involvement of wastewater colloid neutralization. Some colloids are swept together with neutrally charged impurities during sweep flocculation. Such flocs undergo sedimentation, and some negatively charged colloids, responsible for the negative value of zeta potential, are left in treated wastewater.

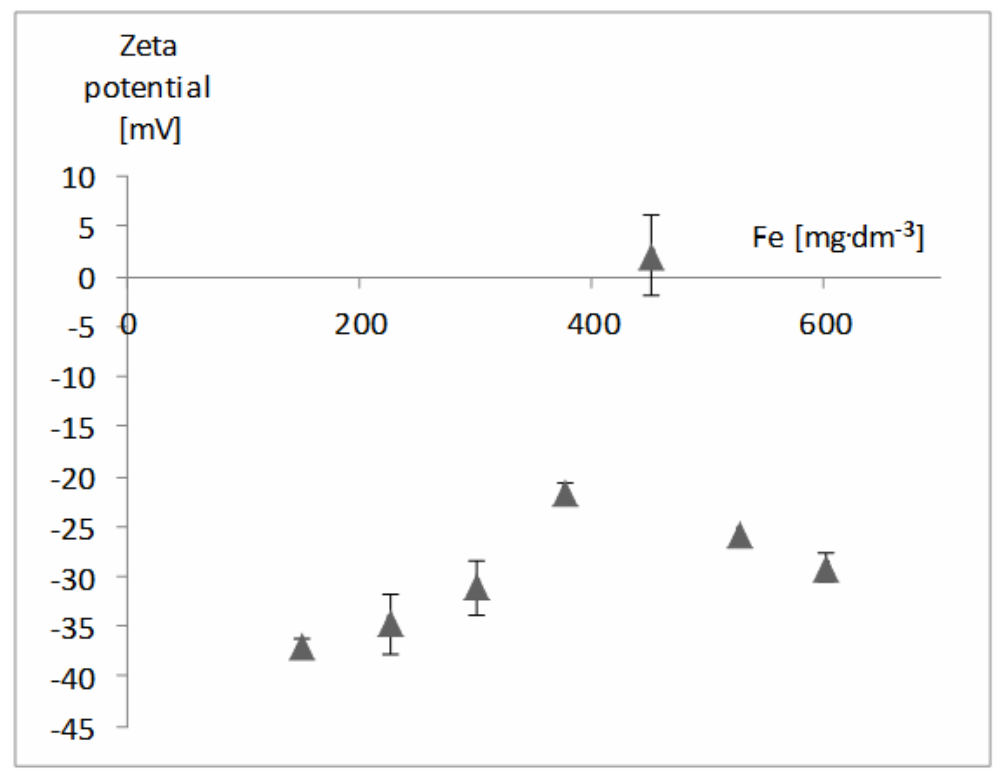

Fig. 6. Changes in zeta potential $\zeta$ of wastewater coagulated with PIX. Values of standard deviation (SD) are introduced on the experimental points

\section{Conclusions}

The analyzed model wastewater was susceptible to treatment by chemical coagulation. The results of laboratory analyses were consistent with the mathematical model relying on a second-degree polynomial, applied in the study. The optimal coagulant dose was precisely determined based on the parabola minimum point. The application of a coagulant dose higher than the optimal dose reduced the effectiveness of wastewater treatment by coagulation. PAC was a more effective and a more efficient coagulant than PIX. The risk of coagulant overdosing was greater with the use of PAC than PIX.

\section{References}

[1] Smoczyński L, Bukowski Z, Wardzyńska R, Załęska-Chróst B, Dłużyńska K. Water Environ Res. 2009;81(4):348-356(9). DOI: 10.2175/106143008X357174.

[2] Ratnaweera H, Odegaard H, Fetting J. Water Sci Technol. 1992;26(5-6):1229-1237.

[3] Huang C, Shiu H. Colloids Surf A 1996;113(1-2):155-163. DOI: 10.1016/0927-7757(96)03543-1.

[4] Jiang JQ, Graham N, Andre C, Kelsall GH, Brandon N. Water Res. 2002;36(16):4064-4078. 
[5] Wang D, Sun W, Xu Y, Tang H, Gregory J. Colloids Surf. A. 2004;243(1-3):1-10. DOI: 10.1016/j.colsurfa.2004.04.073.

[6] Smoczyński L. Pol J Chem. 2000;74:617-1624. ISSN 0137-5083.

[7] Bottero JY, Tchoubar D, Axelos MAV, Quuienne P. Flocculation of silica colloids with hydroxy aluminum polycations. Relation between floc structure and aggregation mechanisms. Langmuir.1988;6(3):596-601.

[8] Smoczyński L, Mróz P, Wardzyńska R, Załęska-Chróst B, Dłużyńska K. Chem Eng. J. 2009;52:146-150. DOI:10.1016/j.cej.2009.04.020

[9] Aguilar MI, Llor M, Soler O, Ortu JF. Water Res. 2002;36(11):2910-2919. DOI: 10.1016/S0043-1354(01)00508-5

[10] Georgiou D, Aivazidis A, Hatiras J, Gimouhopoulos K. Water Res. 2003;37(9):2248-2250. DOI: 10.1016/S0043-1354(02)00481-5

[11] Clark T, Stephenson T. Water Res. 1998;33(7):1730-1735. DOI: 10.1016/S0043-1354(98)00372-8

[12] Edzwald JK, Tobiason JE. Water Sci Tech. 1999;40(9):63-70.

[13] Rossini M, Garcia-Garrido J, Galluzzo M. Water Res. 1999;33(8):1817-1826. DOI: 10.1016/S0043-1354(98)00367-4.

[14] Duan J, Gregory J. Adv Colloid Interfac. 2003;100-102:475-502. DOI: 10.1016/S0001-8686(02)00067-2.

[15] Ratnaweera H. Overview of coagulant dosing control. In: Chemical Water and Wastewater Treatment. Vol. VII. Hahn HH, Hoffman E, Ødegaard H, editors. London: IWA Publishing; 2004:3-13.

[16] Rodrigo MA, Cañizares P, Buitrón C, Sáez C. Electrochim Acta. 2010;55:8160-8164. DOI: 10.1016/j.electacta.2010.01.053.

[17] Lyklema J. Colloids Surf A. 2006;291(1-3):3-12. DOI: 10.1016/j.colsurfa.2006.06.043.

[18] Xagoraraki I, Harrington GW. J Environ Eng. 2004;130(12):1424-1432. DOI: 10.1061/(ASCE)0733-9372(2004)130:12(1424).

[19] Bouyer D, Escudié R, Liné A. Safety Environ Protect. 2005;83:22-30. DOI: 10.1205/psep.03109.

[20] HACH DR/2000 Spectrophotometer Handbook Procedure Manual. Loveland, USA: Hach Company; 1993.

[21] Bottero JY, Bersillion JL. Aluminum and Iron III Chemistry. Adv Chem Ser. American Society. Washington: 1989;219:425-442.

[22] Pernitsky DJ, Edzwald JK. J. Water Supply: Res Tech. 2003;52(6):395-406.

[23] Armirtharajah A, Mills MK. J. Am Water Work As. 1982;74(4):210-216.

[24] Namasivayam C, Sangetha D. J Colloid Interface Sci. 2004;280:359-365. DOI: 10.1016/j.jcis.2004.08.015.

[25] Srivastava VC, Mall ID, Mishra IM. Colloids Surf A. 2005;260(1-3):17-28. DOI: 10.1016/j.colsurfa.2005.03.027.

[26] Chen X, Chen G, Yue PL. J Environ Eng. 2000;126:858-863. DOI: 10.1061/(ASCE)07339372(2000)126:9(858).

\title{
DESTABILIZACJA ŚCIEKÓW MODELOWYCH W PROCESIE KOAGULACJI CHEMICZNEJ
}

Katedra Chemii, Wydział Kształtowania Środowiska i Rolnictwa, Uniwersytet Warmińsko-Mazurski w Olsztynie

\begin{abstract}
Abstrakt: W niniejszej pracy przedstawiono, opisano i zinterpretowano wyniki badań laboratoryjnych procesu koagulacji-flokulacji ścieków modelowych. Zastosowane ścieki modelowe okazały się podatne na oczyszczanie metodą koagulacji chemicznej. Zastosowano i porównano dwa komercyjne koagulanty: PAC - wyprodukowany w zakładach chemicznych DEMPOL-ECO oraz PIX - wyprodukowany przez firmę KEMIPOL. Do przedstawienia i analizy uzyskanej bazy danych doświadczalnych z powodzeniem zastosowano model matematyczny w postaci wielomianu drugiego stopnia. Minimum takiej paraboli każdorazowo stanowiła dawka koagulantu precyzyjnie obliczana i traktowana jako dawka optymalna. Zastosowanie wyższej, aniżeli optymalna, dawki koagulantu prowadziło każdorazowo do obniżenia stopnia oczyszczenia koagulowanych ścieków. Szczegółowa analiza wyników usuwania mętności, zawiesin, fosforu ogólnego i zanieczyszczeń określanych w skali ChZT pokazała, że PAC skuteczniej i wydajniej, aniżeli PIX, koagulował badane ścieki modelowe. Jednakże zagrożenie tzw. przedawkowania koagulantu okazało się większe ze strony PAC-u aniżeli przy wykorzystaniu PIX-u.
\end{abstract}

Słowa kluczowe: ścieki syntetyczne, dawka koagulantu, potencjał zeta 